\title{
Seafloor ecosystem functioning: the importance of organic matter priming
}

\author{
Paul van Nugteren · Leon Moodley • \\ Geert-Jan Brummer · Carlo H. R. Heip • \\ Peter M. J. Herman · Jack J. Middelburg
}

Received: 13 June 2008/ Accepted: 1 July 2009/Published online: 18 July 2009

(C) The Author(s) 2009. This article is published with open access at Springerlink.com

\begin{abstract}
Organic matter (OM) remineralization may be considered a key function of the benthic compartment of marine ecosystems and in this study we investigated if the input of labile organic carbon alters mineralization of indigenous sediment $\mathrm{OM}$ (OM priming). Using ${ }^{13} \mathrm{C}$-enriched diatoms as labile tracer carbon, we examined shallowwater sediments (surface and subsurface layers) containing organic carbon of different reactivity under oxic versus anoxic conditions. The background OM decomposition rates of the sediment used ranged from 0.08 to $0.44 \mu \mathrm{mol} \mathrm{C} \mathrm{ml} \mathrm{ws}_{\mathrm{ws}}^{-1} \mathrm{day}^{-1}$. Algal $\mathrm{OM}$ additions induced enhanced levels of background remineralization (priming) up to $31 \%$ and these measured excess fluxes were similar to mineralization of the added highly degradable tracer algal carbon. This suggests that OM priming may be important in marine sediments.
\end{abstract}

\section{Introduction}

Organic matter $(\mathrm{OM})$ remineralization is a key function of the benthic compartment of marine ecosystems and

Communicated by M. Kühl.

P. van Nugteren · L. Moodley $(\bowtie) \cdot$ C. H. R. Heip .

P. M. J. Herman · J. J. Middelburg

Centre for Estuarine and Marine Ecology,

Netherlands Institute of Ecology (NIOO-KNAW),

Korringaweg 7, 4401 NT Yerseke, The Netherlands

e-mail: 1.moodley@nioo.knaw.nl

G.-J. Brummer · C. H. R. Heip

Royal Netherlands Institute for Sea Research (NIOZ),

Den Burg, Texel, The Netherlands although extensively studied, it remains a subject of focus due to the complexity of factors and processes involved (Wakeham and Canuel 2006). It is generally thought that microbes fulfill a key role in OM recycling (e.g., Harvey 2006) but when present fauna may be responsible for a significant part of sediment community OM respiration (Heip et al. 1995, 2001). Recent short-term experimental studies utilizing isotope tracer carbon confirm the key role of bacteria, but demonstrate that fauna directly alter the fate of incoming fresh OM (Moodley et al. 2002, 2005a; Witte et al. 2003a). Fauna my out-compete bacteria and direct uptake of OM (feeding) delays short-term OM respiration (Kristensen et al. 1992; Witte et al. 2003b). Furthermore, the recent manipulation experiment studies suggest that a major impact of community structure on seafloor functioning is through bioturbation by large fauna: maintaining habitat heterogeneity (Thrush et al. 2006a) and enhancing $\mathrm{OM}$ recycling primarily through fauna-induced irrigation of deeper sediment layers and enhanced sediment-water solute exchange (Biles et al. 2002; MermillodBlondin et al. 2004; Lohrer et al. 2004; Michaud et al. 2005; Thrush et al. 2006a; Meysman et al. 2006). Simultaneously however, the same fauna-induced displacement of sediment particles (bioturbation) results in mixing and displacement of settled OM into deeper sediment layers (Levin et al. 1997); this may lead to the strong dilution of the fresh OM (Mayer et al. 2001) directly influencing biota accessibility to this OM and subsequent degradation pathways. In addition, depending on the mode of bioturbation, OM removal from contact with oxygenated waters may slow down remineralization of this fresh OM relative to rates under oxic conditions at the sediment-water interface (Sun et al. 2002a; Josefson et al. 2002).

Another potentially related but not well-documented phenomenon in marine sediments is OM "priming"; the 
input of relatively fresh and labile organic carbon (OC) may alter remineralization of indigenous, relatively older and less reactive $\mathrm{OM}$, i.e., the remineralization of more refractory components may be linked to the decay of labile components (Canfield 1994; Aller 1994; Hee et al. 2001). This process is sometimes referred to as "cometabolism" (Wakeham and Canuel 2006). Priming has been studied intensively in soils and its effect may be positive or absent (e.g., Hamer and Marschner 2005a, b; Hoyle et al. 2008). OM priming may potentially also be an important factor in regulating the carbon balance in marine sediments, but there is very limited evidence for "priming" in marine sediments. Kristensen and Holmer (2001) added fresh diatom and hay detritus to shallow-water surface sediment and found no clear evidence for priming. Turnewitsch et al. (2007) studied the interaction between fresh and refractory organic matter for nitrogen mineralization and found nonlinear effects but the results were not conclusive regarding priming. Using a pulse-tracer experiment, Hee et al. (2001) provided convincing evidence that the addition of fresh substrates stimulated the decomposition of relict, indigenous OM.

Here, we report on sediment-water slurry incubations examining $\mathrm{OM}$ priming in shallow-water sediments. We utilized algal carbon, pre-enriched with ${ }^{13} \mathrm{C}$ as tracer $\mathrm{OM}$ addition, because its diagenetic end product it is easily isotopically distinguished from that of the indigenous $\mathrm{OM}$ (Blair et al. 1996). We examined continental shelf subtidal (surface and subsurface layers) and estuarine intertidal sediments that were expected to contain OM of contrasting reactivity (Dauwe and Middelburg 1998). Given that the OM degradation may be redox sensitive (e.g., Bianchi et al. 2000; Sun et al. 1993, 2002a, b; Kristensen et al. 1995; Harvey et al. 1995; Kristensen and Holmer 2001) and that oxygen exposure time may be key in determining OM preservation in marine sediments (e.g., Hartnett et al. 1998; Sun and Dai 2005; Moodley et al. 2005b), incubation of the surface and subsurface subtidal sediments were done both under oxic and anoxic conditions. In addition, we used two different concentrations of "priming" OM to explore the consequences of dilution of fresh OM that occurs due to downward bioturbation of recently settled OM.

\section{Materials and methods}

\section{Sediment sampling}

Sediment was collected from a shallow site in the Skagerrak, eastern North Sea (59-m water depth, 5750 N, $\left.10^{\circ} 01 \mathrm{E}\right)$ using a box corer on board the RV Pelagia in April 2002. A total of six cores (14 cm i.d.; $30-\mathrm{cm}$ deep) were taken from three different box cores and sediment from the surface layer $(0-2 \mathrm{~cm})$ and a deeper layer $(18$ $20 \mathrm{~cm}$ ) were pooled separately and thoroughly homogenized manually. No large macrofauna or shell debris were observed in the sediment and the sediment was therefore not sieved. Subsamples were taken from each pooled depth interval and frozen at $-80^{\circ} \mathrm{C}$ for later analysis of sediment characteristics.

Intertidal surface sediment (upper $2 \mathrm{~cm}$ ) was collected during low tide from a mudflat in the Scheldt estuary (Southwest Netherlands, 51 26 N, $3^{\circ} 57$ E, April 2003 using the RV Luctor). Moist sediment from this site was first sieved (500 $\mu \mathrm{m}$ mesh opening) to remove large fauna and shell debris. Site-specific details are provided in Table 1.

\section{Experimental set-up}

Sediment-water slurries were prepared basically according to Dauwe et al. (2001); volumes of $10 \mathrm{ml}$ wet sediment (sampled by filling a cutoff syringe) were transferred into preweighed $80 \mathrm{ml}$ glass incubation bottles (Chrompack). Sediment without any additions was used to determine background $\mathrm{OM}$ remineralization rates. As a source of tracer and possible priming OM, we used the cosmopolitan diatom Skeletonema costatum cultured, isotope labeled and

Table 1 Origin and characteristics of the sediment used for sediment-water slurry incubations

\begin{tabular}{|c|c|c|c|c|c|c|c|}
\hline Sampling site & $\begin{array}{l}\text { Water } \\
\text { depth (m) }\end{array}$ & $\begin{array}{l}\text { Sediment } \\
\text { sample }(\mathrm{cm})\end{array}$ & $\begin{array}{l}\text { Median grain } \\
\text { size }(\mu \mathrm{m})\end{array}$ & $\begin{array}{l}\text { Percentage of } \\
\text { silt }(<63 \mu \mathrm{m})\end{array}$ & $\begin{array}{l}\text { TOC } \\
\text { content }(\%)\end{array}$ & $\delta^{13} \mathrm{C}-\mathrm{OM}$ & $\begin{array}{l}\delta^{13} \mathrm{C}- \\
\text { Carbonate }\end{array}$ \\
\hline \multirow[t]{2}{*}{ Skagerrak $57^{\circ} 50 \mathrm{~N}, 10^{\circ} 01 \mathrm{E}$} & \multirow[t]{2}{*}{ Subtidal $59 \mathrm{~m}$} & Subtidal $0-2$ & $41.2(0.7)$ & $69.4(0.5)$ & $0.86(0.02)$ & $-22(-19)$ & $+0.5(0.0)$ \\
\hline & & Subtidal $18-20$ & $45.8(0.2)$ & $65.5(0.1)$ & $0.79(0.01)$ & $-22(-19)$ & $+0.6(0.1)$ \\
\hline Scheldt estuary $51^{\circ} 26 \mathrm{~N}, 3^{\circ} 57 \mathrm{E}$ & Intertidal low tide & Intertidal 0-2 & $109(0.8)$ & $19.4(0.1)$ & $0.24(0.10)$ & $-19(-16)$ & $-0.17(0.1)$ \\
\hline
\end{tabular}

Average median grain size $(\mu \mathrm{m})$, average percentage of silt (fraction smaller than $63 \mu \mathrm{m}$ ), average total organic carbon content (percentage of TOC; $n=2$ and standard errors in brackets)

Also given is the measured stable carbon isotope signature (\%) of bulk sediment organic matter (OM) with in brackets the value of "reactive" OM (that of bacteria PLFA, see "Materials and methods")

In the last column, measured $\delta^{13} \mathrm{C}$ of sediment bulk carbonate (SE) 
harvested as described in Moodley et al. (2000). This produced axenic diatom carbon with $\sim 27 \%{ }^{13} \mathrm{C}\left(\delta^{13} \mathrm{C}=\right.$ $+32,000 \%$ ).

For Skagerrak sediment, vials containing sediment were divided into three major groups: no extra additions were series to determine background $\mathrm{OM}$ remineralization rates and for the two experimental treatments different amounts of tracer algal carbon additions were employed. An additional experimental factor was the division into oxic and anoxic incubations (see below). Algal material was suspended in rinsing medium (artificial seawater without bicarbonate used for initial rinsing and isolation of ${ }^{13}$ C-labeled diatoms (Moodley et al. 2000), of which $1 \mathrm{ml}$ was added to each vial; two concentrations were used, equivalent to an addition of 0.52 and $5.2 \mu \mathrm{mol} \mathrm{C}$ per ml wet sediment (ws). For the intertidal surface sediment, single additions were made equivalent to $\sim 3.6 \mu \mathrm{mol} \mathrm{C}$ per $\mathrm{ml}$ sediment. Owing to the logistic limitations, anoxic incubations were not possible and these were incubated only under oxic conditions, but for three different durations (7, 14 and 21 days in the dark at $\left.15^{\circ} \mathrm{C}\right)$. Skagerrak sediments were incubated for 21 days in the dark $\left(12^{\circ} \mathrm{C}\right)$.

The final step of slurry preparation was the addition of filtered $(0.2 \mu \mathrm{m})$ bottom water $(10 \mathrm{ml})$ followed by sealing with screw caps fitted with rubber septa. After being thoroughly mixed by hand shaking, slurries $(\sim 20 \mathrm{ml}$ sediment water and $\sim 60-\mathrm{ml}$ headspace) were purged for 5 min with either $\mathrm{N}_{2}$ or $\mathrm{N}_{2}: \mathrm{O}_{2}(80: 20)$ for anoxic and oxic slurries, respectively (Dauwe et al. 2001). Oxygenation was verified using a needle-type oxygen microsensor (needle allows penetration of septum to measure oxygen without having to open the bottles, Presens, Germany) that was also used to confirm that there was oxygen remaining in the oxic incubation waters at the end. In total, 11 experimental treatments ( 3 replicates each) were conducted (see Table 3) that differed in sediment origin (surface versus subsurface subtidal sediment versus intertidal estuarine surface sediment), load of labile carbon addition (single versus tenfold carbon addition), the presence or absence of oxygen in incubations of subtidal sediments and three time intervals for intertidal surface sediment. These treatments will be compared with simultaneously executed background incubations without label OM additions (control-background). In addition, a set of slurries were prepared and immediately processed (see below) to establish initial conditions (used as start values of concentrations and isotope signatures of $\Sigma \mathrm{CO}_{2}$ ). Flasks with subtidal sediments were manually shaken twice a day during the first 3 days on board ship, after which they were transferred to the laboratory in a temperature-controlled vehicle and then on continuously shaken (automatically rotated). Intertidal sediment-water slurries were manually shaken once daily.
Measurements and analysis

Sediment granulometry was determined on freeze-dried sediment samples with a Malvern Mastersizer 2000 and sediment porosity was calculated from water content (weight loss on freeze drying) assuming a dry density of $2.55 \mathrm{~kg} \mathrm{dm}^{-3}$ (Dauwe et al. 2001).

In this study, we utilized the evolution of $\mathrm{CO}_{2}$ as a measure of $\mathrm{OM}$ remineralization because Dauwe et al. (2001) have shown that methane production can be neglected in these sediments (even for anoxic conditions). The analysis of $\mathrm{CO}_{2}$ concentrations and $\delta^{13} \mathrm{C}-\mathrm{CO}_{2}$ was combined in one measurement, i.e., the area counts given in a standard output of an isotope ratio measurement on a mass spectrometer was used to calculate concentrations (e.g., Moodley et al. 2002). For the slurries, we first measured $\mathrm{CO}_{2}$ concentration and $\delta^{13} \mathrm{C}-\mathrm{CO}_{2}$ in the incubation bottle headspace by sampling $1,000 \mu \mathrm{l}$ through septum with a gas-tight syringe. Subsequently, the vials were centrifuged ( $3 \mathrm{~min}$ at $900 \mathrm{rpm}$ ) to obtain sediment-free water samples from which $\sim 3 \mathrm{ml}$ was transferred through a GFF filter into a helium pre-flushed vial sealed with a shrimp cap with rubber septum. Exact water volume was determined by weight. Following the acidification $(10 \mu \mathrm{l}$ 99\% $\mathrm{H}_{3} \mathrm{PO}_{4}$ per $\mathrm{ml}$ sample) headspace $\Sigma \mathrm{CO}_{2}$ concentration and $\delta^{13} \mathrm{C}-\Sigma \mathrm{CO}_{2}$ were measured using a Carlo Erba 1106 Elemental Analyser coupled online with a Finnigan Delta $\mathrm{S}$ isotope ratio mass spectrometer. Total $\Sigma \mathrm{CO}_{2}$ was the sum of that measured directly in the slurry bottle gas-phase- and liquid-phase upon acidification. Carbon isotopes are expressed in the delta notation $\left(\delta^{13} \mathrm{C}\right)$ relative to Vienna Pee Dee Belemnite.

Of the total $\Sigma \mathrm{CO}_{2}$ produced during the incubations, a part may be due to carbonate dissolution, not necessarily associated with OM remineralization (e.g., Anderson et al. 1986). Carbonate dissolution can be traced through changes in $\mathrm{Ca}^{+}$ion concentration (e.g., Hulthe et al. 1998) or alternatively, the fraction of dissolved inorganic carbon originating from carbonate dissolution may be traced through shift in carbon isotope signatures of $\mathrm{CO}_{2}$ produced in the incubations (e.g., Ogrinc and Faganeli 2003, Ogrinc et al. 2003; Hu and Burdige 2007) and then the maximum contribution from carbonate dissolution can be estimated from a two-end member linear mixing model (e.g., Fry and Sherr 1984; Levin and Michener 2002).

We calculated the $\delta^{13} \mathrm{C}$ of the $\Sigma \mathrm{CO}_{2}$ produced during the incubations through mass balance; first, for the $\delta^{13} \mathrm{C}$ of the $\Sigma \mathrm{CO}_{2}$ at the end of the incubation in this closed system, we used the concentration-weighed average of that measured in the incubation bottle headspace and that in the water phase upon acidification after $1 \%$ correction for fractionation between $\mathrm{CO}_{2}$ gas in the aqueous and gaseous phase (Mook et al. 1974). Then, the $\delta^{13} \mathrm{C}$ of $\Sigma \mathrm{CO}_{2}$ 
produced was calculated from the difference in $\delta^{13} \Sigma \mathrm{CO}_{2}$ at the start and end of the incubations calculated as:

$$
\begin{aligned}
\delta^{13} \mathrm{C}_{\text {prod }}= & \left(\left(\left[\Sigma \mathrm{CO}_{2 \text { end }}\right] \times \delta^{13}-\Sigma \mathrm{CO}_{2 \text { end }}\right)\right. \\
- & \left.\left(\left(\Sigma \mathrm{CO}_{2 \text { start }}\right) \times \delta^{13}-\Sigma \mathrm{CO}_{2 \text { start }}\right)\right) / \\
& \left(\left[\Sigma \mathrm{CO}_{2 \text { end }}\right]-\left[\Sigma \mathrm{CO}_{2 \text { start }}\right] .\right.
\end{aligned}
$$

Subsequently, a two-end member linear mixing model was used to estimate maximum $\Sigma \mathrm{CO}_{2}$ originating from carbonate dissolution as:

$F_{\text {diss }}=\left(\delta_{\text {prod }}^{13}-\delta_{\text {om }}^{13}\right) /\left(\delta_{\text {carb }}^{13}-\delta_{\text {om }}^{13}\right)$,

where $\delta_{\text {prod }}^{13}, \delta_{\text {om }}^{13}$, and $\delta_{\text {carb }}^{13}$ are the carbon isotope signatures of $\Sigma \mathrm{CO}_{2}$ produced, sediment organic matter and bulk carbonate, respectively. The carbon isotope signature of bulk sediment organic matter (TOC) does not necessarily reflect the reactive pool of $\mathrm{OC}$, therefore, for the isotope value of the organic matter end member we used that of bacteria as a measure of reactive organic matter (estimated via bacteria-specific PLFA - polar lipid derived fatty acids): $-16 \%$ for the intertidal sediment (Middelburg et al. 2000) after applying a 4\% correction for fractionation between PLFA and total bacterial biomass (Boschker et al. 1999) and $-19 \%$ for Skagerrak subtidal sediment (Boschker, personal communication 2007). Sediment bulk carbonate carbon isotope signatures were measured on a
Thermo Finnigan Delta + mass spectrometer equipped with a GASBENCH II preparation device (Vrije Universiteit, Amsterdam, The Netherlands). Approximately $30 \mathrm{mg}$ of homogenized freeze-dried sediment sample, placed in a He-filled 10-ml exetainer vial is digested in concentrated $\mathrm{H}_{3} \mathrm{PO}_{4}$ at a temperature of $45^{\circ} \mathrm{C}$. Subsequently the $\mathrm{CO}_{2}-\mathrm{He}$ gas mixture is transported to the GASBENCH II by the use of a He flow through a flushing needle system. In the GASBENCH, water is extracted from the gas, by the use of NAFION tubing, and $\mathrm{CO}_{2}$ is analyzed in the mass spectrometer after the separation of other gases in a GC column.

The fraction dissolved inorganic carbon originating from carbonate dissolution $\left(F_{\text {diss }}\right)$, as estimated from the two-end member linear mixing model, was then subtracted from total $\Sigma \mathrm{CO}_{2}$ produced in the control incubations to obtain background indigenous $\mathrm{OM}$ remineralization. Indigenous $\mathrm{OM}$ decomposition in amended treatments was obtained by further subtracting $\mathrm{CO}_{2}$ originating from tracer $\mathrm{C}_{\text {org }}$ decomposition. The use of ${ }^{13} \mathrm{C}$-enriched tracer $\mathrm{OM}$ prevents direct calculation of dissolution in individual amended treatments, as described above for the different sediment types, but assuming constant dissolution dynamics for a given sediment type, we applied that determined on the corresponding background sediment (Table 2). At this point, it is important to note that the correction for

\begin{tabular}{|c|c|c|c|c|c|c|c|c|}
\hline \multirow[t]{2}{*}{ Sediment sample } & \multicolumn{2}{|c|}{ End $\left[\Sigma \mathrm{CO}_{2}\right]\left(\mu \mathrm{mol} \mathrm{ml}^{-1}\right)$} & \multicolumn{2}{|c|}{ Tracer OM respired } & \multicolumn{2}{|c|}{$\delta^{13} \mathrm{C}$ of $\Sigma \mathrm{CO}_{2}$ produced (\%o) } & \multicolumn{2}{|c|}{ Maximum $\Sigma \mathrm{CO}_{2}$ from C-dissolution (\%) } \\
\hline & Ox & Anox & Ox & Anox & Ox & Anox & Ox & Anox \\
\hline \multicolumn{9}{|l|}{ Subtidal 0-2 } \\
\hline C-bkgrd & 8.99 & 6.92 & & & -11.8 & -13.9 & 37.0 & 26.2 \\
\hline$+1 \times$ tracer $\mathrm{OM}$ & 9.29 & 7.20 & 0.11 & 0.09 & +288.2 & +332.5 & 37.0 & 26.2 \\
\hline$+10 \times$ tracer $\mathrm{OM}$ & 10.88 & 7.44 & 1.46 & 1.06 & $+3,136.8$ & $+3,201.0$ & 37.0 & 26.2 \\
\hline \multicolumn{9}{|l|}{ Subtidal 18-20 } \\
\hline C-bkgrd & 12.29 & 4.98 & & & -2.2 & -16.8 & 86.0 & 11.2 \\
\hline$+1 \times$ tracer $\mathrm{OM}$ & 12.09 & 5.17 & 0.06 & 0.11 & +137.8 & +824.9 & 86.0 & 11.2 \\
\hline$+10 \times$ tracer $\mathrm{OM}$ & 14.33 & 6.87 & 0.80 & 1.36 & $+1,496.7$ & $+6,655.3$ & 86.0 & 11.2 \\
\hline \multicolumn{9}{|l|}{ Intertidal } \\
\hline 7 day C-bkgrd & 9.60 & & & & -13.4 & & 16.6 & \\
\hline +Tracer OM & 11.00 & & 0.71 & & $+3,126.9$ & & 16.6 & \\
\hline 14 day C-bkgrd & 11.74 & & & & -14.5 & & 9.8 & \\
\hline +Tracer OM & 13.47 & & 1.08 & & $+2,831.9$ & & 9.8 & \\
\hline 21 day C-bkgrd & 13.70 & & & & -14.5 & & 9.6 & \\
\hline +Tracer OM & 15.92 & & 1.21 & & $+2,480.0$ & & 9.6 & \\
\hline
\end{tabular}

Table 2 Average total end $\Sigma \mathrm{CO}_{2}$ concentration in the different incubations $\left(\mu \mathrm{mol} \mathrm{C} \mathrm{ml}{ }^{-1}\right.$ ) and the amount of tracer carbon re-mineralized $\left(\mu \mathrm{mol} \mathrm{C} \mathrm{ml} \mathrm{ws}_{\mathrm{ws}}^{-1}\right)$ in the amended treatments under oxic (ox) versus anoxic (anox) conditions

The $\delta^{13} \mathrm{C}$ of $\Sigma \mathrm{CO}_{2}$ produced (\%) is shown in the fourth column followed by the maximum contribution of carbonate dissolution (\%) to $\Sigma \mathrm{CO}$ produced

Maximum dissolution was taken to be constant per given sediment and dissolution in amended treatments therefore equal to corresponding control-background dissolution values

All values are average of $n=3$ 
carbonate dissolution is subtraction of a sediment typespecific fraction of the $\Sigma \mathrm{CO}_{2}$ produced and not a fixed amount of the $\mathrm{CO}_{2}$ production. Therefore, the addition of $\mathrm{OM}$ leading to higher $\mathrm{CO}_{2}$ production would also result in a corresponding larger $\Sigma \mathrm{CO}_{2}$ subtraction for dissolution correction.

The calculations can be summarized as follows:

1. Total $\Sigma \mathrm{CO}_{2}\left({ }^{12} \mathrm{C}+{ }^{13} \mathrm{C}\right)$ originating from the strongly labeled algal OM: product of excess ${ }^{13} \mathrm{C}$ (e.g., Middelburg et al. 2000) and end $\Sigma \mathrm{CO}_{2}$ content divided by the fractional abundance of ${ }^{13} \mathrm{C}$ in the $\mathrm{OM}(0.27$; Moodley et al. 2005a).

2. Total $\Sigma \mathrm{CO}_{2}$ produced in background incubations or amended treatments (i.e., sum of metabolic produced $\mathrm{CO}_{2}$ and $\mathrm{CO}_{2}$ from carbon dissolution): end $\Sigma \mathrm{CO}_{2}$ content - start $\Sigma \mathrm{CO}_{2}$ content.

3. Background indigenous OM remineralization: (2) $\left(F_{\text {diss }}\right)$.

4. Indigenous $\mathrm{OM}$ remineralization in amended treatments: $(2)-\left(F_{\text {diss }}\right)-(1)$.

Priming is the difference in indigenous OM remineralization measured in amended treatments and that measured in control-background incubations, expressed as $\mu \mathrm{mol} \mathrm{C} \mathrm{ml}_{\mathrm{ws}}^{-1}$ (wet sediment).

Log-transformed data were analyzed by two-way analysis of variance (ANOVA) followed by pairwise comparisons (Tukey HSD test) using SYSTAT (Systat Inc.).

\section{Results}

Skagerrak, subtidal sediments were fine grained and organic carbon content was similar in surface and subsurface layers; it was much lower in the coarse-grained intertidal sediment (Table 1). The $\delta^{13} \mathrm{C}$ of $\Sigma \mathrm{CO}_{2}$ produced during the control-background incubations ranged from -2.2 to $-16.8 \%$ and revealed different degrees of carbonate dissolution; $10-86 \%$ of the dissolved inorganic carbon originated from carbonate dissolution (Table 2). Subtracting the fraction originating from carbonate dissolution from total $\Sigma \mathrm{CO}_{2}$ produced in the control incubations revealed background $\mathrm{OM}$ remineralization rates in subtidal sediment ranging from 1.6 to $5.5 \mu \mathrm{mol} \mathrm{C} \mathrm{ml} \mathrm{ws}^{-1}$ (21 days incubation; Fig. 1a) and in intertidal sediment these values ranged from 3.8 to $9.3 \mu \mathrm{mol} \mathrm{C} \mathrm{ml}-1$ after 7-21 days of incubation (Fig. 1b). Conversion to daily $\mathrm{OM}$ remineralization rates and $\mathrm{OM}$ reactivity ( $k$, calculated from a single pool as quotients of $\mathrm{CO}_{2}$ production rates and $\mathrm{C}_{\mathrm{org}}$ content) show that subtidal subsurface sediment had approximately four times lower OM reactivity than its surface counterpart

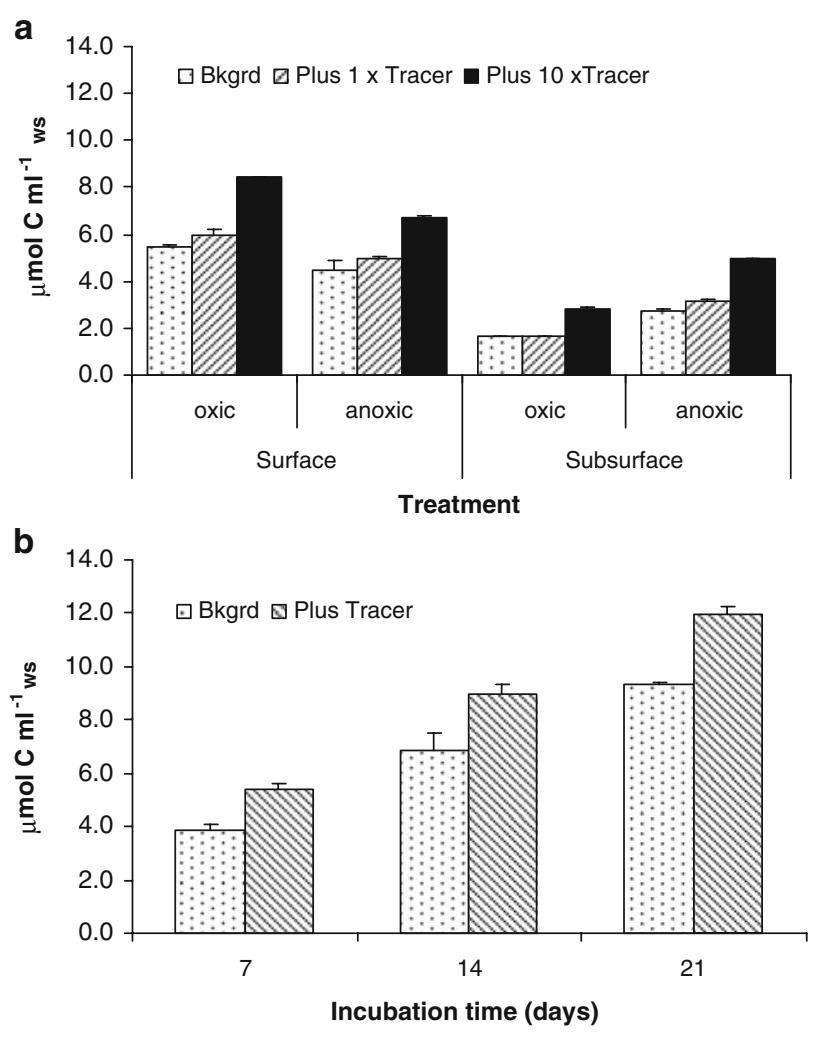

Fig. 1 a The amount of OM remineralized after 21 days of incubation of surface versus subsurface with or without oxygen in background (Bkgrd) and tracer OM amended (single and tenfold load) subtidal sediment, $\mathbf{b}$ the amount of OM remineralized after 7, 14, and 21 days of incubation of intertidal surface sediment under oxic conditions with or with tracer $\mathrm{OM}$ addition. Average $\mu \mathrm{mol} \mathrm{C} \mathrm{ml} \mathrm{Cl}^{-1}$ wet sediment plus standard errors $(n=3)$

and was an order of magnitude less reactive than that of the intertidal sediment (Table 3).

The fresh algal carbon addition significantly enhanced sediment release of $\Sigma \mathrm{CO}_{2}$ in surface and subsurface subtidal sediment both under oxic and anoxic conditions (Fig. 1a); treatments with amendments, especially in the higher OM addition, had higher OM remineralization rates (ANOVA, $P<0.05$; Table 4). Depending on the amount of algal carbon added, sediment total OM remineralization rates were enhanced $4-80 \%$ of background values (Fig. 1a). Similarly, the addition of algal carbon significantly increased total OM remineralization in the intertidal sediments (Table 4; Fig. 1b; increasing background rates by $28-40 \%$ ). However, these overall significant increases in total OM remineralization were only in part due to the respiration of the added carbon (Fig. 2). In the low load amended subtidal sediment, 16-90\% (average $38 \pm 35 \%$ ) of excess originated from tracer respiration (Fig. 2a). For sediment with a tenfold OM addition, 48-79\% (average $64 \pm 13 \%$ ) of excess fluxes originated from the tracer OM (Fig. 2b) and in the intertidal sediment incubations, an 
Table 3 Control-background (C-bkgrd) remineralization rates $\mu \mathrm{mol} \mathrm{C} \mathrm{ml} \mathrm{ws}_{\mathrm{ws}}^{-1} \mathrm{day}^{-1}$ and $\mathrm{OM}$ reactivity $\left(k \times 10^{-4}\right.$ day $\left.^{-1}\right)$ of the different sediment used: average under oxic (ox) and anoxic (anox) conditions

\begin{tabular}{|c|c|c|c|c|c|c|c|c|c|c|c|c|c|c|c|c|}
\hline \multirow[t]{4}{*}{ Sediment sample $(\mathrm{cm})$} & \multirow{2}{*}{\multicolumn{2}{|c|}{$\begin{array}{l}\text { C-bkgrd OM } \\
\text { Remineral }\end{array}$}} & \multirow{2}{*}{\multicolumn{2}{|c|}{$\begin{array}{l}\text { Bkgrd OM } \\
\text { reactivity }(k)\end{array}$}} & \multirow{2}{*}{\multicolumn{4}{|c|}{$\begin{array}{l}\text { Percentage of tracer } \\
\text { carbon respired }\end{array}$}} & \multicolumn{8}{|c|}{ Enhanced OM decomposition } \\
\hline & & & & & & & & & \multicolumn{4}{|c|}{$\begin{array}{l}\text { Percentage of tracer } \\
\text { remineralization }\end{array}$} & \multicolumn{4}{|c|}{$\begin{array}{l}\text { Percentage of bkgrd } \\
\text { remineralization }\end{array}$} \\
\hline & \multirow[t]{2}{*}{$\mathrm{Ox}$} & \multirow[t]{2}{*}{ Anox } & \multirow[t]{2}{*}{ Ox } & \multirow[t]{2}{*}{ Anox } & \multicolumn{2}{|l|}{$\mathrm{Ox}$} & \multicolumn{2}{|c|}{ Anox } & \multicolumn{2}{|l|}{ Ox } & \multicolumn{2}{|c|}{ Anox } & \multicolumn{2}{|l|}{ Ox } & \multicolumn{2}{|c|}{ Anox } \\
\hline & & & & & $1 \times$ & $10 \times$ & $1 \times$ & $10 \times$ & $1 \times$ & $10 \times$ & $1 \times$ & $10 \times$ & $1 \times$ & $10 \times$ & $1 \times$ & $10 \times$ \\
\hline Subtidal 0-2 & 0.26 & 0.21 & 4.4 & 3.7 & 19 & 26 & 16 & 23 & 393 & 108 & 531 & 27 & 8 & 29 & 10 & 7 \\
\hline Subtidal $18-20$ & 0.08 & 0.13 & 0.9 & 1.6 & 11 & 15 & 20 & 25 & 11 & 51 & 300 & 62 & 0.4 & 25 & 12 & 31 \\
\hline Intertidal $0-2$ & 0.44 & - & 16.3 & - & & & & & & & & & & & & \\
\hline Day 7 & & & & & 19.7 & & - & & 120 & - & & & 22 & - & & \\
\hline Day 14 & & & & & 29.9 & & - & & 91 & - & & & 14 & - & & \\
\hline Day 21 & & & & & 33.2 & & - & & 119 & - & & & 15 & - & & \\
\hline
\end{tabular}

Also given is the percent of the tracer OM respired in the different treatments that received a single low $(1 \times)$ and tenfold $(10 \times)$ load of tracer amendment

In the last column, enhanced OM decomposition (priming of indigenous OM) is presented as both percentage of tracer carbon respired and as percentage of $\mathrm{C}$-background $\mathrm{OM}$ remineralization rates, again with $1 \times$ versus $10 \times$ addition under oxic and anoxic conditions

All values are average of $n=3$

average of $48 \%$ of excess originated from the tracer addition (Fig. 2c). Therefore, different fractions of excess fluxes were non-tracer $\mathrm{OM}$ and potentially due to $\mathrm{OM}$ priming evident in all treatments (Table 3; Fig. 2). However, reversed redox conditions for subtidal sediments (anoxic for surface and oxic for subsurface) seemed to be relatively less facilitative for $\mathrm{OM}$ priming (Table 3; Fig. 2b). This is in accordance with the significant (ANOVA, $P<0.05$; Table 4) impact of oxygenation on subtidal $\mathrm{OM}$ decomposition rates (higher rates under oxic conditions for surface sediment, but the opposite for subsurface sediment, Fig. 1a). The significant interaction term for the subsurface subtidal sediment can be attributed to the slightly different response of the $1 \times$ treatment under oxic and anoxic conditions (Fig. 1a). Although quantitatively $\left(\mu \mathrm{mol} \mathrm{C} \mathrm{ml} \mathrm{ws}^{-1}\right)$ the highest priming was found with higher $\mathrm{OM}$ additions, the magnitude of priming was not proportional to the amount of tracer OM added (Fig. 2): tenfold increase in $\mathrm{OM}$ addition did not result in tenfold higher priming. Clear cases of enhancement are seen in surface sediment under oxic conditions and subsurface sediment under anoxic conditions (compare Fig. 2a, b). For the subtidal high $\mathrm{OM}$ additions, priming was equivalent to $7-$ $31 \%$ of background OM remineralization, but equivalent to $27-100 \%$ of remineralization of the highly degradable tracer added carbon (Table 3; Fig. 2b). In the low-load subtidal incubations, priming was equivalent to $<1-12 \%$ of background $\mathrm{OM}$ remineralization and $11-500 \%$ of remineralization of the highly degradable tracer added carbon (Table 3; Fig. 2a).

As in the case of subtidal sediment, tracer addition to intertidal sediment clearly impacted OM remineralization
Table 4 Results of two-way ANOVA of OM remineralization rates (log-transformed $\mu \mathrm{mol} \mathrm{C} \mathrm{ml} \mathrm{ws}_{\mathrm{ws}}^{-1}$ ) in the different sediment samples

\begin{tabular}{lrrrrl}
\hline Source & \multicolumn{1}{l}{ SS } & \multicolumn{1}{l}{ MS } & \multicolumn{1}{l}{$F$ ratio } & \multicolumn{1}{l}{$P$} \\
\hline Subtidal surface & & & & & \\
Treatment & 0.086 & 2 & 0.043 & 49.193 & 0.000 \\
Oxygenation & 0.031 & 1 & 0.031 & 34.982 & 0.000 \\
Interaction & 0.000 & 2 & 0.000 & 0.186 & 0.833 \\
Error & 0.009 & 10 & 0.001 & & \\
Subtidal subsurface & & & & \\
Treatment & 0.214 & 2 & 0.107 & $1,085.722$ & 0.000 \\
Oxygenation & 0.277 & 1 & 0.277 & $2,820.872$ & 0.000 \\
Interaction & 0.001 & 2 & 0.001 & 10.084 & 0.003 \\
Error & 0.001 & 12 & 0.000 & & \\
Intertidal surface & & & & & \\
Treatment & 0.051 & 1 & 0.051 & 44.460 & 0.000 \\
Time & 0.273 & 2 & 0.136 & 118.734 & 0.000 \\
Interaction & 0.001 & 2 & 0.000 & 0.400 & 0.683 \\
Error & 0.009 & 8 & 0.001 & & \\
\hline
\end{tabular}

Treatment is no amendments versus different $\mathrm{OM}$ additions

rates. First, there was significantly more OM decomposition over time and $\mathrm{OM}$ amendment significantly increased OM decomposition rates (ANOVA, $P<0.05$, Table 4; Fig. 1b). Priming was also evident in intertidal sediment already after 7 days and ranged from 91 to $120 \%$ of that derived from the tracer $\mathrm{OM}$, equivalent to on an average $17.2 \pm 3.5 \%$ of background OM remineralization (Fig. 2c; Table 3).

Although the sediment material used in this study differed about as much as one order of magnitude in OM 

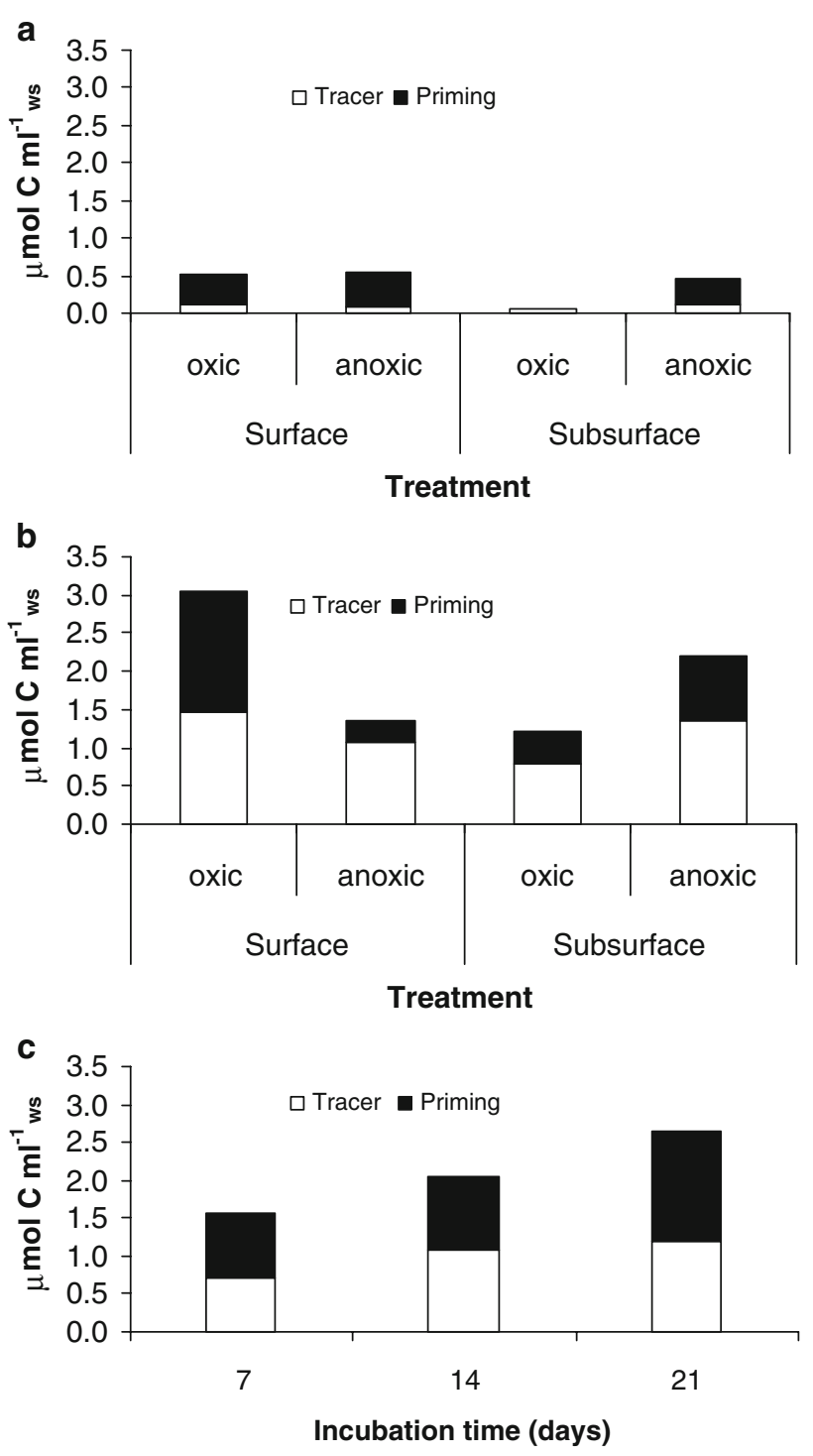

Fig. 2 Division of excess fluxes above background rates between that from tracer $\mathrm{OM}$ and that of $\mathrm{OM}$ priming: a Twenty-one day incubations of subtidal sediment under different redox conditions amended with a single load of tracer OM. b Same as a, but with a tenfold tracer $\mathrm{OM}$ addition. c Intertidal sediment after 7, 14 and 21 days incubation. Average $\mu \mathrm{mol} \mathrm{C} \mathrm{ml}{ }^{-1}$ wet sediment $(n=3)$

reactivity, the priming effect after 21 days was rather similar for comparable treatments and the priming resulted in a 15-29\% increase in background OM mineralization in Skagerrak subtidal and intertidal estuarine sediments incubated under oxic conditions with similar high OM additions (Table 3 ).

For subtidal sediment incubations, the amount of $\Sigma \mathrm{CO}_{2}$ that originated from tracer $\mathrm{OM}$ was proportional to the amount added $\left(\sim 12\right.$-fold increase in amount $\Sigma \mathrm{CO}_{2}$ originating from tracer $\mathrm{OM}$ with tenfold higher tracer addition, Fig. 2). For the high-load additions, a similar fraction of the tracer OM was re-mineralized within 21 days in subtidal sediments under different redox conditions (23$26 \%$ ) except lowered value of $\sim 15 \%$ for subsurface sediment under oxic conditions (Table 3). A similar trend among the treatments was also evident in the low-load OM amendments; albeit with a slightly lower percent of tracer carbon respired after 21 days (16-20\%; Table 3). In the case of intertidal sediment approximately $33 \%$ of the added tracer was respired within 21 days (Table 3 ).

\section{Discussion}

The concept and consequences of priming have been discussed in the marine literature (e.g., Graf 1992; Canfield 1994; Aller 1994; Gribsholt and Kristensen 2002), but few conclusive results have been reported because of experimental difficulties. It is not only necessary to detect the small enhancement of total OM mineralization due to labile carbon addition, but it is also needed to partition this excess mineralization between tracer and enhanced indigenous carbon mineralization. Moreover, carbonate dissolution may complicate interpretation of dissolved inorganic production rates as proxy for mineralization. Closed, small volume sediment-water incubations as used in this study may exhibit elevated sensitivity to carbonate dissolution due to the possible exhaustion of alkalinity or buffer capacity. This is particularly evident in the subtidal subsurface sediment under oxic conditions where the high incubation end $\Sigma \mathrm{CO}_{2}$ concentration was primarily due to carbonate dissolution. Oxidation of compounds, such as ammonium that often accumulate in deeper sediment layers not exposed to bioturbation (e.g., Nielsen et al. 2004; Mermillod-Blondin et al. 2005) can lead to extensive loss of alkalinity (Wilson and Thomson 1998; Soetaert et al. 2007). This is supported by more limited dissolution under anoxic conditions (Table 2).

It is clearly evident that sediments may differ strongly in their dissolution dynamics (Table 2) depending on origin and redox conditions and highlights the importance of individual estimates per sediment type and treatment as conducted in this study (Table 2). At the same time, this draws attention to the application of dissolution dynamics determined for background to amended treatments, but we estimate that this has not led to gross overestimation of priming because of underestimating dissolution. First, dissolution dynamics are expected to be similar because OM additions were by no means unusually high. In addressing OM priming, the amount of matter added should preferably be close to in situ OM fluxes. In this study, using the $\mathrm{CO}_{2}$ production rates, we estimate $\mathrm{OM}$ input for the subtidal surface sediment at $2.6 \mathrm{mmol} \mathrm{C} \mathrm{m}^{-2} \mathrm{day}^{-1}$ and for the intertidal sediment at $4.4 \mathrm{mmol} \mathrm{C} \mathrm{m}^{-2} \mathrm{day}^{-1}$. This means that the additions 
used for the subtidal sediment equal approximately 10$100 \%$ of in situ input for that experiment period of 21 days. For the intertidal sediments, this is estimated at being $40 \%$ of a 3-week input. Therefore, the overall amounts employed here are within ranges expected to prevail in the field. The amount that can be mixed deep down in the subtidal sediment used in this study is unknown, but it is expected to represent a small fraction of that settling on the surface (that may vary depending on the mode of bioturbation) and the $10 \%$ of estimated incoming fluxes employed is not unrealistically high.

Secondly, OM amendment treatments were otherwise identical to background incubations and as used in this study, carbonate dissolution correction (calculated as percentage of $\mathrm{CO}_{2}$ production) is proportional to the amount of $\mathrm{CO}_{2}$ produced thereby accounting for potential increase in the dissolution coupled to enhanced OM decomposition (tracer and indigenous $\mathrm{OM}$ ). In addition, the two end mixing model method represents a maximum percentage contribution of dissolution, so that priming could in fact be larger. Therefore, isotope insensitive complementary tools, such as changes in $\mathrm{Ca}+$ ion concentration (e.g., Hulthe et al. 1998) may constitute an important refinement in this method of addressing the subject $\mathrm{OM}$ priming in marine sediments.

Another potential complication of our incubation technique relates to rapid changes in redox conditions as imposed in this study, which may destroy a portion of the microbes with consequences for the net efficiency of remineralization (Aller 1994). However, overall, a substantial fraction of fresh tracer OM was readily and rapidly processed and respired by the sediment microbiota, consistent with recent isotope tracer studies (e.g., Blair et al. 1996; Moodley et al. 2005a, Buhring et al. 2006). For tenfold tracer OM addition in the subtidal sediment, 23$26 \%$ was respired within 21 days except for a low $15 \%$ in subsurface sediment exposed to oxic conditions (Table 3). In contrast to surface layers, deeper subsurface layers are not naturally exposed to changing redox conditions and this lowered activity may reflect reduced flexibility of deep subsurface microbes. After 21 days of incubation, $33 \pm 3 \%$ of the added carbon was respired in intertidal sediments (Table 3 ) indicating that coarse permeable sediments may indeed be favorable for microbial OM remineralization despite an expected relatively low-microbial standing stock (Dauwe et al. 2001; Buhring et al. 2006).

The results of this study clearly revealed that input of fresh OM can potentially enhance remineralization rates of native OM both under oxic and anoxic conditions. There are very few data to compare with our results. Kristensen and Holmer (2001) incubated thin layers of homogenized surface sediment in a continuous flow system and found no significant effects that could be attributed to priming.
Turnewitsch et al. (2007) focused on the interaction of labile and refractory organic matter on nitrogen cycling and reported a transient positive effect on nitrogen mineralization, but no significant effect on particulate nitrogen pools. Hee et al. (2001) incubated coastal deep subsurface sediments retrieved from below the active remineralization zone and demonstrated priming under anoxic conditions using both dissolved inorganic carbon and carbon isotope data as we did.

In contrast to marine sediments, OM priming in soils has been the target of numerous studies and it has been established that it is strongly influenced by the diversity and concentration of substrates employed. Moreover, priming may be evident, but substrate addition may also inhibit $\mathrm{OM}$ degradation and its magnitude can vary strongly and depends on the concentration of the substrate added (e.g., Fontaine et al. 2003; Kuzyakov et al. 2000; Hamer and Marschner 2005a, b; Waldrop and Firestone 2004; Brant et al. 2006). These studies also revealed that priming in soils can exceed background remineralization rates, while it represented only a small fraction of background OM remineralization in our study (up to $31 \%$, Table 3). However, the rates of these enhanced fluxes were in the range of remineralization rates measured for the highly reactive and degradable amended OM (Fig. 2). Given that OM lability is a prime factor governing OM remineralization (Wakeham and Canuel 2006 and references therein), this magnitude of priming, therefore, albeit a small percentage of background $\mathrm{OM}$ remineralization may be considered highly relevant.

Our experiment revealed that even a very small addition of fresh OM induced OM priming (Fig. 2). Consistently, Mondini et al. (2006) showed that the addition of trace amounts of different simple and complex substrates can induce immediate, significant activation of soil microbes. However, with a high load, there seems to be preferential uptake of fresh OM resulting in relatively decreased priming (compare Fig. 2a, b). Although this study demonstrates that $\mathrm{OM}$ priming may also be prevalent in marine sediments and, therefore, potentially an important determinant of the final carbon balance, clearly more experimental work is required. We expected that input of fresh OM would have the strongest stimulation on microbial activity under anoxic conditions (remineralization is generally more complete in presence of oxygen) and in sediments with relatively less reactive native OM. This does seem to be the case: priming as percentage of controlbackground remineralization was indeed highest in subtidal subsurface sediment under anoxic incubations (31\%, Table 3). However, priming was similarly high in oxic subtidal surface sediment incubations (29\%) and intertidal sediment (15\%) with relatively high OM reactivity (Table 3). In addition, the highest absolute amount primed 
( $\mu \mathrm{mol} \mathrm{C} \mathrm{ml}_{\mathrm{ws}}^{-1}$ ) was 1.43 in the intertidal sediment after 21 days and 1.58 in the subtidal sediments (oxic surface with tenfold OM additions, Fig. 2). Moreover, the actual mechanisms involved or driving priming are still unclear (e.g., Hee et al. 2001; Hamer and Marschner 2005b; Fontaine et al. 2003). Since the initial proposal of OM priming (Löhnis 1926), it has been a subject of debate whether or not priming was an artifact: priming may not reflect increase in native soil organic matter remineralization, but remineralization of bacterial biomass replaced by new tracer substrate derived biomass. However, studies including soil microbial biomass dynamics confirm that true priming does occur (e.g., Fontaine et al. 2004a and references therein; Kuzyakov et al. 2007) and recently further insight into microbial dynamics involved in soil OM priming have been gained through the application of compound-specific isotope analysis (bacteria-specific fatty acid biomarkers, e.g., Waldrop and Firestone 2004; Brant et al. 2006). Overall for soils, it seems that energy-rich substrate additions rapidly induce shifts in microbial community structure and activity. Depending not only on the reactivity and standing stock of native OM, but also on the substrate added (composition and quantity); priming may be absent, neutral or positive (Fontaine et al. 2004b and references therein). Clearly more experiments with marine sediments are required and although small volume sediment-slurry incubations may be convenient, intact sediment incubated in flow through systems including microbial dynamics and diversity analysis will provide a more complete assessment of the ecological significance of OM priming. Finally, although experimental mineralization rates may deviate from field values, it does not invalidate the study of OM priming which is a comparisonbased approach employing same physical conditions for all treatments. Irrespective, this study shows that organic matter priming may indeed occur in marine sediments. This highlights a potential impact of bioturbation (mixing and displacement of sediment by macrofauna) on sediment OM mineralization that is rarely considered. Bioturbation by large organisms has been repeatedly observed to enhance sediment OM remineralization primarily through oxygenation of subsurface sediments (e.g., Kristensen 2000; Meysman et al. 2006). This can now be extended with OM priming driven by the same down-core mixing of incoming fresh OM. This link between OM priming and fauna activity is further supports the hypothesis that basic seafloor ecological processes are strongly linked to the structure of seafloor communities (Waldbusser et al. 2004; Lohrer et al. 2004; Thrush et al. 2006b; Mermillod-Blondin and Rosenberg 2006; Raffaelli 2006) and is further substantiates that bioturbation by large organisms may strongly govern the carbon flow pathways and the organic carbon balance in marine sediments (e.g., Bianchi et al.
2000; Moodley et al. 2005a; Thrush et al. 2006a; Meysman et al. 2006.

Acknowledgments Special thanks to Lennart van Ijzerloo for technical assistance and the captain and crew of the R.V. Pelagia and the R.V. Luctor for excellent services. Peter van Breugel and Marco Houtekamer are acknowledged for carrying out different laboratory analysis. Special thanks to Suzan Verdegaal and Hubert Vonhof (Faculty of Earth and Life Sciences, Vrije University, Amsterdam, The Netherlands) for sediment bulk carbonate carbon isotope measurements. Pim van Avesaath and Nicole Dijkman are acknowledged for valuable discussions. Detailed and highly constructive reviews by two anonymous reviewers greatly improved the manuscript. This research was supported by the Netherlands Organization of Scientific Research (PIONIER 833.02.2006). This is publication number 4581 of the Netherlands Institute of Ecology (NIOO-KNAW), Yerseke.

Open Access This article is distributed under the terms of the Creative Commons Attribution Noncommercial License which permits any noncommercial use, distribution, and reproduction in any medium, provided the original author(s) and source are credited.

\section{References}

Aller RC (1994) Bioturbation and remineralization of sedimentary organic matter: effects of redox oscillation. Chem Geol 114:331345

Anderson LG, Hall PO, Iverfeldt A, van der Rutgers Loeff MM, Sundby B, Westerland SFG (1986) Benthic respiration measured by total carbonate production. Limnol Oceanogr 31:319-329

Bianchi TS, Johansson B, Elmgren R (2000) Breakdown of phytoplankton pigments in Baltic sediments: effects of anoxia and loss of deposit-feeding macrofauna. J Exp Mar Biol Ecol 251:161-183

Biles CL, Paterson DM, Ford RB, Solan M, Raffaelli DG (2002) Bioturbation, ecosystem functioning and community structure. Hydrol Earth Sys Sci 6:999-1005

Blair NE, Levin LA, De Master DJ, Plaia G (1996) The short-term fate of fresh algal carbon in continental slope sediments. Limnol Oceanogr 41:1208-1219

Boschker HTS, Brouwer JFC, Cappenberg TE (1999) The contribution of macrophyte-derived organic matter to microbial biomass in salt marsh sediments: stable carbon isotope analysis of microbial biomarkers. Limnol Oceanogr 44:309-319

Brant JB, Sulzman EW, Myrold DD (2006) Microbial community utilization of added carbon substrates in response to long-term carbon input manipulation. Soil Biol Biochem 38:2219-2232

Buhring SI, Ehrenhauss S, Kamp A, Moodley L, Witte U (2006) Enhanced benthic activity in sandy sublittoral sediments: evidence from C-13 tracer experiments. Mar Biol Res 2:120-129

Canfield DE (1994) Factors influencing organic carbon preservation in marine sediments. Chem Geol 114:315-329

Dauwe B, Middelburg JJ (1998) Amino acids and hexosamines as indicators of organic matter degradation state in North Sea sediments. Limnol Oceanogr 43:782-798

Dauwe B, Middelburg JJ, Herman PMJ (2001) Effect of oxygen on the degradability of organic matter in subtidal and intertidal sediments of the North Sea area. Mar Ecol Prog Ser 215:13-22

Fontaine S, Mariotti A, Abbadie L (2003) The priming effect of organic matter: a question of microbial competition? Soil Biol Biochem 35:837-843

Fontaine S, Bardoux G, Benest D, Verdier B, Mariotti A, Abbadie L (2004a) Mechanisms of priming effect in a Savannah soil amended with cellulose. Soil Sci Soc Am J 68:125-131 
Fontaine S, Bardoux G, Abbadie L, Mariotti A (2004b) Carbon input to soil decrease soil carbon content. Ecol Lett 7:314-320

Fry B, Sherr EB (1984) $\delta^{13} \mathrm{C}$ measurements as indicators of carbon flow in marine and fresh water systems. Contrib Mar Sci 27:13-46

Graf G (1992) Benthic-pelagic coupling: a benthic view. Oceanogr Mar Biol Ann Rev 30:149-190

Gribsholt B, Kristensen E (2002) Effects of bioturbation and plant roots on salt marsh biogeochemistry: a mesocosm study. Mar Ecol Prog Ser 241:71-87

Hamer U, Marschner B (2005a) Priming effects in different soil types induced by fructose, alanine, oxalic acid and catechol additions. Soil Biol Biochem 37:445-454

Hamer U, Marschner B (2005b) Priming effects in soils after combined and repeated substrate additions. Geoderma 128:38-51

Hartnett HE, Keil RG, Hedges JI, Devol AH (1998) Influence of oxygen exposure time on organic carbon preservation in continental margin sediments. Nature 391:572-574

Harvey HR (2006) Sources and cycling of organic matter in the marine water column. In: Volkman JK (ed) Marine organic matter: the handbook of environmental chemistry, vol 2. Part N. Springer, Berlin, pp 1-25

Harvey HR, Tuttle JH, Bell JT (1995) Kinetics of phytoplankton decay during simulated sedimentation-changes in biochemical composition and microbial activity under oxic and anoxic conditions. Geochim Cosmochim Acta 59:3367-3377

Hee CA, Pease TK, Alperin MJ, Martens CS (2001) Dissolved organic carbon production and consumption in anoxic marine sediments: a pulsed-tracer experiment. Limnol Oceanogr 46:1908-1920

Heip CHR, Goosen NK, Herman PMJ, Kromkamp J, Middelburg JJ, Soetaert K (1995) Production and consumption of biological particles in temperate tidal estuaries. Oceanogr Mar Biol Annu Rev 33:1-149

Heip CHR, Duineveld GCA, Flach E, Graf G, Helder W, Herman PMJ, Lavaleye M, Middelburg JJ, Pfannkuche O, Soetaert K, Soltwedel T, de Stigter H, Thomsen L, Van Averbeke J, de Wilde P (2001) The role of the benthic biota in sedimentary metabolism and sediment-water exchange processes in the Goban Spur area (NE Atlantic). Deep Sea Res Part II 48:3223-3243

Hoyle FC, Murphy DV, Brookes PC (2008) Microbial response to the addition of glucose in low-fertility soils. Biol Fertil Soils 44:571-579

Hu XP, Burdige DJ (2007) Enriched stable carbon isotopes in the pore waters of carbonate sediments dominated by seagrasses: evidence for coupled carbonate dissolution and reprecipitation. Geochim Cosmochim Acta 71:129-144

Hulthe G, Hulth S, Hall POJ (1998) Effect of oxygen on degradation rate of refractory and labile organic matter in continental margin sediments. Geochim Cosmochim Acta 62:1319-1328

Josefson AB, Forbes TL, Rosenberg R (2002) Fate of phytodetritus in marine sediments: functional importance of macrofaunal community. Mar Ecol Prog Ser 230:71-85

Kristensen E (2000) Organic matter diagenisis at the oxic/anoxic interface in coastal marine sediments, with emphasis on the role of burrowing animals. Hydrobiologia 426:1-24

Kristensen E, Holmer M (2001) Decomposition of plant materials in marine sediment exposed to different electron acceptors $\left(\mathrm{O}_{2}\right.$, $\mathrm{NO}_{3}{ }^{-}$, and $\mathrm{SO}_{4}{ }^{2-}$ ), with emphasis on substrate origin, degradation kinetics, and the role of bioturbation. Geochim Cosmochim Acta 65:419-433

Kristensen E, Andersen FO, Blackburn TH (1992) Effects of benthic macrofauna and temperature on degradation of macroalgal detritus: the fate of organic carbon. Limnol Oceanogr 37:1404-1419

Kristensen E, Ahmed SI, Devol AH (1995) Aerobic and anaerobic decomposition of organic matter in marine sediment: which is fastest? Limnol Oceanogr 40:1430-1437
Kuzyakov Y, Friedel JK, Stahr K (2000) review of mechanisms and quantification of priming effects. Soil Biol Biochem 32:14851498

Kuzyakov Y, Hill PW, Jones DL (2007) Root exudate components change litter decomposition in a simulated rhizosphere depending on temperature. Plant Soil 290:305

Levin LA, Michener RH (2002) Isotopic evidence for chemosynthesis-bases nutrition of macrobenthos: the lightness of being at Pacific methane seeps. Limnol Oceanogr 47:1336-1345

Levin L, Blair N, DeMaster D, Plaia G, Fornes W, Martin C, Thomas C (1997) Rapid subduction of organic matter by maldanid polychaetes on the North Carolina slope. J Mar Res 55:595-611

Löhnis F (1926) Nitrogen availability in green manures. Soil Sci 22:253-290

Lohrer AM, Thrush SF, Gibbs MM (2004) Bioturbators enhance ecosystem function through complex biogeochemical interactions. Nature 431:1092-1095

Mayer LM, Jumars PA, Bock MJ, Vetter YA, Schmidt JL (2001) Two roads to sparagmos: extracellular digestion of sedimentary food by bacterial inoculation versus deposit-feeding. In: Aller JY, Woodin SA, Aller RC (eds) Organism-sediment interactions. University of South Carolina Press, Columbia, pp 335-347

Mermillod-Blondin F, Rosenberg R (2006) Ecosystem engineering: the impact of bioturbation on biogeochemical processes in marine and freshwater benthic habitats. Aquat Sci 68:434-442

Mermillod-Blondin F, Rosenberg R, Francois-Carcaillet F, Norling K, Mauclaire L (2004) Influence of bioturbation by three benthic infaunal species on microbial communities and biogeochemical processes in marine sediment. Aquat Microb Ecol 36:271-284

Mermillod-Blondin F, Francois-Carcaillet F, Rosenberg R (2005) Biodiversity of benthic invertebrates and organic matter processing in shallow marine sediments: an experimental study. J Exp Mar Biol Ecol 315:187-209

Meysman FJR, Middelburg JJ, Heip CHR (2006) Bioturbation: a fresh look at Darwin's last idea. Trends Ecol Evol 21:688-695

Michaud E, Desrosiers G, Mermillod-Blondin F, Sundby B, Stora G (2005) The functional group approach to bioturbation: the effects of biodiffusers and gallery-diffusers of the Macoma baltic community on sediment oxygen uptake. J Exp Mar Biol Ecol 326:77-88

Middelburg JJ, Barranguet C, Boschker HTS, Herman PMJ, Moens T, Heip CHR (2000) The fate of intertidal microphytobentos: an in situ ${ }^{13} \mathrm{C}$ labeling study. Limnol Oceanogr 45:1224-1234

Mondini C, Cayuela ML, Sanchez-Monedero MA, Roig Brookes PC (2006) Soil microbial biomass activation by trace amounts of readily available substrate. Biol Fertil Soils 42:542-549

Moodley L, Boschker HTS, Middelburg JJ, Pel R, Herman PMJ, de Deckere EMGT, Heip CHR (2000) Ecological significance of benthic foraminifera: C-13 labelling experiments. Mar Ecol Prog Ser 202:29-289

Moodley L, Middelburg JJ, Boschker HTS, Duineveld GCA, Pel R, Herman PMJ, Heip CHR (2002) Bacteria and Foraminifera: key players in a short-term deep-sea benthic response to phytodetritus. Mar Ecol Prog Ser 236:23-29

Moodley L, Middelburg JJ, Soetaert K, Boschker HTS, Herman PMJ, Heip CHR (2005a) Similar rapid response to phytodetritus deposition in shallow and deep-sea sediments. J Mar Res 63:457-469

Moodley L, Middelburg JJ, Herman PMJ, Soetaert K, de Lange GJ (2005b) Oxygenation and organic-matter preservation in marine sediments: direct experimental evidence from ancient organic carbon-rich deposits. Geology 33:889-892

Mook WG, Bommerson JC, Staverman WH (1974) Carbon isotope fractionation between dissolved and gaseous carbon dioxide. Earth Planet Sci Lett 22:169-176

Nielsen OL, Gribsholt B, Kreistensen E, Revsbech NP (2004) Microscale distribution of oxygen and nitrate in sediment 
inhabited by Nereis diversicolor: spatial patterns and estimated reaction rates. Aquat Microb Ecol 34:23-32

Ogrinc N, Faganeli J (2003) Stable carbon isotopes in pore waters of coastal marine sediments (the Gulf of Trieste, N Adriatic). Acta Chim Slovenica 50:645-662

Ogrinc N, Faganeli J, Pezdic J (2003) Determination of organic carbon remineralization in near-shore marine sediments (Gulf of Trieste, Northern Adriatic) using stable carbon isotopes. Org Geochem 34:681-692

Raffaelli D (2006) Biodiversity and ecosystem functioning: issues of scale and trophic complexity. Mar Ecol Prog Ser 311:285-294

Soetaert K, Hofmann AF, Middelburg JJ, Meysman FJR (2007) The effect of biogeochemical processes on $\mathrm{pH}$. Mar Chem 105:30-51

Sun MY, Dai JH (2005) Relative influences of bioturbation and physical mixing on degradation of bloom-derived particulate organic matter: clue from microcosm experiments. Mar Chem 96:201-218

Sun M-Y, Aller RC, Lee C (1993) Laboratory studies of oxic and anoxic degradation of chlorophyll $a$ in Long Island sound sediments. Geochim Cosmochim Acta 57:147-157

Sun MY, Aller RC, Lee C, Wakeham SG (2002a) Effects of oxygen and redox oscillation on degradation of cell-associated lipids in surficial marine sediments. Geochim Cosmochim Acta 66:20032012

Sun MY, Cai WJ, Joye SB, Ding HB, Dai JH, Hollibaugh JT (2002b) Degradation of algal lipids in microcosm sediments with different mixing regimes. Org Geochem 33:445-459

Thrush SF, Hewitt JE, Gibbs M, Lundquist C, Norkko A (2006a) Functional role of large organisms in intertidal communities: community effects and ecosystem function. Ecosystems 9:1029_ 1040

Thrush SF, Gray JS, Hewitt JE, Ugland KI (2006b) Predicting the effects of habitat homogenization on marine biodiversity. Ecol Appl 16:1636-1642

Turnewitsch R, Domeyer B, Graf G (2007) Experimental evidence for an effect of early-diagenetic interaction between labile and refractory marine sedimentary organic matter on nitrogen dynamics. J Sea Res 57:270-280

Wakeham SG, Canuel EA (2006) Degradation and preservation of organic matter in marine sediments. In: Volkman JK (ed) Marine organic matter: the handbook of environmental chemistry, vol 2. Part N. Springer, Berlin, pp 295-321

Waldbusser GG, Marinelli RL, Whitlatch RB, Visscher PT (2004) The effects of infaunal biodiversity on biogeochemistry of coastal marine sediments. Limnol Oceanogr 49:1482-1492

Waldrop MP, Firestone MK (2004) Microbial community utilization of recalcitrant and simple carbon compounds: impact of oakwoodland plant communities. Oecologia 138:275-284

Wilson TRS, Thomson J (1998) Calcite dissolution accompanying early diagenesis in turbiditic deep ocean sediments. Geochim Cosmochim Acta 62:2087-2096

Witte U, Aberle N, Sand M, Wenzhofer F (2003a) Rapid response of a deep-sea benthic community to POM enrichment: an in situ experimental study. Mar Ecol Prog Ser 251:27-36

Witte U, Wenzhofer F, Sommer S, Boetius A, Heinz P, Aberle N, Sand M, Cremer A, Abraham WR, Jorgensen BB, Pfannkuche O (2003b) In situ experimental evidence of the fate of a phytodetritus pulse at the abyssal sea floor. Nature 424:763-766 